The success of most problems in insect suppression work rests principally on good business management and entomologists should not be slow in recognizing this fact.

Vice-President E. C. Cotton: This completes the program of the horticultural inspectors.

In the absence of the President, I will call for the next paper,

\title{
THE MORPHOLOGY, BEHAVIOR AND SUSCEPTIBILITY OF THE EGGS OF THREE IMPORTED APPLE PLANT LICE
}

By Alvah Peterson, New Brunswich, N. J.

(Withdrawn for publication elsewhere)

Vice-President E. C. Cotton: The paper is open for discussion now.

Mr. P. J. PArrott: As I understand the speaker, you make the application of lime sulphur solely to destroy the eggs.

Mr. Alvah Peterson: No, because at that period the eggs are hatching and the combination will kill the nymphs and the eggs.

Mr. P. J. Parrott: In New York we are advising our farmers to hold back the spraying, because we aim at the nymphs.

Mr. Alvah Peterson: In New Jersey the eggs have not all hatched at a time when we apply the material. Aphis avenoe in our state hatches ten days before $A$ phis sorbi. To wait until the eggs are all hatched would be too late.

Mr. C. P. Ginlette: Through how long a period did you find the eggs of any one species hatching normally?

Mr. Alvah Peterson: Ten days-usually less than that. If you have a warm spell during the hatching period, they will hatch in four or five days, but if it is cold and wet the hatching period may extend over a period of ten days for one species.

Mr. P. J. PARrott: In your field experiments, when the trees have been thoroughly sprayed at the time indicated by your third picture, did you have any difficulty in getting complete killing of the insects?

Mr. Alvah Peterson: I can give you an example of that in one orchard where the man was very thorough in his work. We tried the nicotine combined with the lime sulphur, and even though this man was very thorough in his work, he did not get 100 per cent. Our experiments also showed that the eggs of $A$ phis sorbi and pomi are not as susceptible to sprays as avence. 
MR. P. J. PARRotT: But you are making that recommendation?

Mr. Alvah Peterson: Yes, because it is the best recommendation we have, so far as we know at the present time.

Mr. W. J. SchoEne: The hatching of these eggs and the appearance of the aphids have been noted for several past seasons, not only by the entomologists but also members of the other departments. The fact has been noticed that the eggs hatch many weeks in advance of the time when the buds show green at the tips. We found them late in February and early in March, when the aphid had no chance to obtain food.

Mr. Alvah Peterson: What species?

Mr. W. J. Schoene: Avence.

Mr. R. C. Ossurs: I would like to ask Dr. Peterson whether his observations indicate that avenee is of any importance in getting out the test? What experiments have you to show that the nicotine should be used one to four hundred, as against one to nine hundred? The bulk of the United States probably uses nicotine sulphate at the rate of three quarters of a pint to one hundred gallons, and it would be very interesting to know why New Jersey reduces the recommendations to one to four hundred?

Mr. Alvah Peterson: In the first place I might say that our recommendation is one to five hundred.

In respect to the difference in the amount of injury done by the various species, of course that which is done by the avence is least of all. I fully expect to see injury done by avena this coming spring for they undoubtedly will be abundant, because I know of one orchard today in New Jersey where the eggs are actually so abundant that you cannot touch a square inch of the large trunk of the tree without crushing a number of eggs. When these eggs hatch and come out and attack the young, green buds, it stands to reason that there will be some injury, even though it may not be as marked as that of sorbi or pomi.

In respect to one to five hundred or one to a thousand, or whatever might be recommended in using nicotine sulphate, I might say that we do not get as good a clean-up with one to a thousand as we do with one to five hundred. Mr. Barclay carried on experiments in his orchards with one to five hundred and one to a thousand, which showed conclusively that one to five hundred is much better. Dr. Headlee has carried out some experiments along that same line. Probably he could give you some pointers on this.

Mr. T. J. Headlee: We have been interested in the study of the control of the apple aphis for three or four years, and we were lead to take it up because of the failure of some of our orchardists to obtain protection by the application of nicotine at the cluster cup or pink bud 
spray. The same year that this failure occurred we made a laboratory test to determine the minimum dosage which would destroy the rosy aphis. At the time the test was made the rosy aphis was present in all stages from the slaty colored stem mother to the winged forms. The results of that test are shown in the following table:

Frrect or Nicotine Splats on Rost Aphis

\begin{tabular}{c|l|c}
\hline \hline $\begin{array}{c}\text { Number of } \\
\text { leaves }\end{array}$ & \multicolumn{1}{|c}{ Treatment } & $\begin{array}{c}\text { Percentage Living at } \\
\text { End of Experiment }\end{array}$ \\
\hline 2 & Water only & 100 \\
\hline 2 & "Black Leaf 40" (1 part) + water (900 parts) & 60 \\
\hline 2 & "Black Leaf 40" (1 part) + water (900 parts) + soap (2 lbs. to 50 gal.) & 10 \\
\hline 2 & "Black Lesf 40" (1 part) + water (700 parts) + soap (2 lbs. to 50 gal.) & 1 \\
\hline 2 & "Black Leaf 40" (1 part) + water (500 parts) & 10 \\
\hline 2 & "Black Leaf 40" (1 part) + water (500 parts) + soap (2 lbs. to 50 gal.) & 0 \\
\hline
\end{tabular}

The following year we laid out some blocks of seven-year-old apple and made the series of treatment indicated in the following table:

Scmangy of Regtets in ApHis Control. Expertment

\begin{tabular}{|c|c|c|c|c|}
\hline $\begin{array}{c}\text { Plot } \\
\text { Numbers }\end{array}$ & Treatment & $\begin{array}{l}\text { Total Number } \\
\text { of Buds } \\
\text { Examined }\end{array}$ & $\begin{array}{l}\text { Total Number } \\
\text { of Aphis } \\
\text { Found }\end{array}$ & $\begin{array}{l}\text { Number of } \\
\text { A phis Per } \\
100 \text { Buds }\end{array}$ \\
\hline $1 \& 1$ & $\begin{array}{l}\text { Lime-sulfur ( } 1 \text { to } 9) \text { during dormancy; "Black Lesf } 40 " \\
(1 \text { to } 1,000)+80 a p(2 \text { lbs. to } 50 \text { gal.) when buds showed } \\
\text { green }\end{array}$ & 281 & 5 & 1.7 \\
\hline $2 \star 2$ & $\begin{array}{l}\text { Lime-oulfur ( } 1 \text { to } 9 \text { ) during dormancy; lime-ulfur ( } 1 \text { to } 9) \\
+ \text { "Black Leaf } 40 "(1 \text { to } 1,000) \text { when buds showed grcen }\end{array}$ & 282 & 18 & 6.3 \\
\hline $3 \& 3$ & Lime-sulfur ( 1 to 9 ) when the buds showed green & 320 & 304 & 95 . \\
\hline 484 & $\begin{array}{l}\text { Lime-gulfur }(1 \text { to } 9)+\text { "Black Leaf } 40 \text { " (1 to } 500) \text { when } \\
\text { buds ahowed green }\end{array}$ & 339 & 11 & 3.2 \\
\hline 5 \& 5 & $\begin{array}{l}\text { Lime-gulfur }(1 \text { to } 0)+\text { "Black Leaf } 40 " \text { " }(1 \text { to } 1,000) \text { when } \\
\text { buds ahowed green }\end{array}$ & $33 !$ & 156 & 47.1 \\
\hline $6 \& 6$ & Scalecile (1 to 15) while buds were dormant & 306 & 37 & 12. \\
\hline $7 \notin 7$ & Scalecide (1 to 15) when the buts showed green & 303 & 0 & 2.9 \\
\hline
\end{tabular}

Nots.-Unsprayed trecs showed average of 600 aphis per 100 burls.

A large block of trees of the same ake and variety in the same orchard were sprayed with lime-sulfur (1 to 9$)$ during dormancy. These trees showed an average of 6 aphis to 100 buds.

Mr. John Barclay of Cranbury was the orchardist coöperating and the man who personally made the treatments. Throughout my entire experience I have never seen an orchardist or an entomologist who made treatments any more thoroughly than Mr. Barclay and I believe therefore that the data obtained are reliable. This table shows that the spray of winter-strength lime-sulphur to which 40 per cent nicotine was added at the rate of 1 to 1000 left fifteen times more living aphis 
on the tree than the spray composed of winter-strength lime-sulphur to which 40 per cent nicotine was added at the rate of 1 to 500 . No man can say without a foreknowledge of the weather what degree of reduction will constitute a control. It is therefore advisable to obtain the greatest degree of reduction possible, and the mixture of winterstrength lime-sulphur to which 40 per cent nicotine has been added at the rate of 1 to 500 appears to give a much greater reduction than the less strengths of nicotine.

President E. D. Ball: I will now call for the next paper by $\mathrm{Mr}$. A. L. Quaintance.

Mr. A. L. Quaintance: I wish to explain that I prepared no paper. When I saw that there were already on the program papers dealing with the Japanese beetle and oriental fruit moth, it appeared to me preferable to discuss and perhaps elaborate on the papers presented, if opportunity offered, rather than to present another formal paper. Unfortunately I missed hearing the papers presented by Professor Cory and Mr. Goodwin, but have no doubt that the subjects were fully covered.

There are two or three questions relative to quarantine measures, however, and the question of possibility of the eradication which may be of interest to some of the membership. The quarantine question is, of course, in the hands of the state entomologists concerned. As to the eradication of the oriental fruit moth and Japanese beetle, I would say that in my opinion while such eradication is of course within the realms of possibility, provided large funds are available and very drastic measures are adopted, yet I doubt the feasibility and expediency of a program of this character.

Perhaps all of these questions have been discussed by Mr. Goodwin and Professor Cory and I would not wish to repeat anything since we have still before us a very interesting program. It is suggested therefore that unless there are particular questions in which members are interested that further time be not taken up with this subject.

Mr. P. J. Parrotr: We people from other parts of the country do not often have the opportunity of seeing Mr. Quaintance, much less to hear him, and I would like very much to have him discuss both of these insects and give us his impression of the situation.

Mr. A. L. Quaintance: Referring first to the Japanese beetle: We do not know, of course, how much of a pest the Japanese beetle is going to be. While the adults attack a large variety of food plants, some of which are injured to an important extent, it is very probable that such damage can be effectively checked by the use of arsenical poisons sprayed or dusted over the plants being injured. The beetles feed upon numerous ornamentals which are now, as a rule, but little sprayed, but which for the most part could readily be sprayed without 
unduly complicating their profitable cultivation. We are quite uncertain as to the amount of damage to expect from the larvæ attacking the live roots of plants. This type of injury, if important, would probably prove difficult of correction.

I think entomologists are warranted in assuming that a newly introduced insect will become a troublesome pest and arrange their work on that basis. A change of policy, of course, can be adopted as soon as it is clear that the insect in question will not be especially troublesome. Acting on this plan the Bureau of Entomology, coöperating with Dr. T. J. Headlee, New Jersey State Entomologist, has undertaken work looking toward the eradication and control of the insect. Mr. Goodwin doubtless fully explained to you this morning the character of field work now under way. If its eradication cannot be accomplished, our efforts, it is hoped, will result in restricting its spread until its economic status will have been better determined.

Our inspection records for 1917 of the distribution of the Japanese beetle were not very extensive, and while we have been able to make fairly thorough inspecting during 1918, we are unable to decide on account of the uncertainty of the thoroughness of previous inspection work, whether the insect is spreading rapidly, moderately or not at all. Personally, I am of the opinion that it spread during 1918 to a considerable extent.

Several state entomologists have made inquiry concerning what quarantine measures, if any, should be undertaken to prevent the introduction of the insect into their states. I think it would be dangerous to permit the shipment from the infested area of plants with soil around the roots. I understand that Dr. Headlee has in effect regulations to prevent the movement of such plants. There is danger also of the distribution of the beetles in green, sugar or field corn, since the beetles freely penetrate the tips of the ears of green corn to feed upon the milky kernels. The danger of the spread of the insect in this way seemed so important that a quarantine of green sweet corn was established by the Federal Horticultural Board, effective June 1, 1919, and adequate machinery will be provided for the inspection, certification and movement of this crop.

Several things interfered with the vigorous prosecution of the field work planned for 1918, as insufficient funds, difficulty in obtaining in time machinery and insecticides, and difficulty in obtaining labor. We hope to surmount all of these difficulties next year and feel that 1919 and 1920 will be our big years in the work, and which will prove conclusively what can be hoped for towards the eradication of the Japanese beetle.

The establishment in the United States of the oriental fruit moth has 
awakened a good deal of interest among entomologists and fruit growers. It may be that possibilities for injury by this insect have been over-emphasized. There is, however, considerable reason for fearing that the insect may become a first-class pest of deciduous fruits. It belongs to the same genus with the codling-moth. There are developed in the latitude of Washington four or five broods of larvæ each year, and the behavior of the insect in orchards coming under the speaker's observation leaves no doubt as to the capabilities of the insect for harm. Notwithstanding all of these facts the oriental fruit moth may, of course, succumb to the action of native parasites, or for other reasons fail to develop into a serious pest, a result which is much to be hoped for.

Funds were available under the appropriation for stimulating agriculture to make a rather thorough survey of the United States to determine the distribution of the insect. There were employed at one time or another some fifteen or eighteen inspectors, and while it was possible to inspect only the more important fruit-growing regions, yet the scouting was so arranged that had the insect been generally scattered over the country, it would have certainly been detected. Inspections were made of the peach belt of the South and representative peach and apple orchards were inspected in the middle Atlantic States, the middle West, the Rocky Mountain States and the Pacific Coast. Briefly the insect was found to occur only in a strip of territory that may be said to border on each side of the railroads between Washington and New York. In the environs of Washington, we have a rather severe infestation extending a few miles south into Virginia and northwestward to about Leesburg, Va., where large commercial peach orchards are located. The insect is pretty well present over southern Maryland, extending northward through Frederick and Washington Counties, Md. There is an infestation at Lancaster, Pa., and it has been taken in the environs of Philadelphia. Northern New Jersey is more or less infested, and the insect is rather generally present on ornamental and other Prunus spp. on Manhattan and Long Islands. There is an infestation in southern Connecticut and extreme southern New York.

Considerable difference of opinion prevails among entomologists as to the practicability of quarantine measures in the restriction of spread of this species, and perhaps something should be said on this subject. It should be borne in mind that the oriental fruit moth infests fruit, especially peaches, apples, pears and quinces and also the tender tips of nursery stock and orchard trees, particularly the peach. We may fairly judge of the probable effectiveness of quarantine measures in preventing the spread of the oriental fruit moth in fruit by what we know of the value of such efforts in preventing the spread of the codling-moth. In the case of an insect infesting fruit any adequate inspec- 
tion and certification as to freedom from the insect would be exceedingly difficult to arrange, and would require a large force of inspectors and funds to make the work reasonably efficient. Even under such a system it is practically certain that the pest would gradually be disseminated in spite of all efforts to the contrary. A more logical plan would appear to be to provide for the inspection of orchards and quarantine movement into non-infested areas of fruit from orchards found to be infested.

In the case of nursery stock, the danger of distribution in the speaker's judgment is slight. Of course it is possible that some of the larvæ might still be in the tips of the twigs when the trees are dug and shipped in early fall, but in the case of nursery stock handled in the usual way, larvæ in most cases would have deserted the twigs and sought suitable places for the construction of cocoons in which to hibernate. Probably only in rare instances would the cocoon be found along the trunk of the little nursery tree, but more likely on the ground under accumulated trash, etc. Any quarantine plan to be effective, therefore, should pay especial attention to restricting the movement of infested fruit, the quarantine on nursery stock being merely incidental. In view of the extreme difficulty, if not impossibility, of restricting the spread of this insect by quarantine measures, such quarantines are, in the speaker's opinion, of doubtful utility and should receive the careful attention of state entomologists before being put in effect. Surely coöperation among state officials should be had and a uniform policy adopted, if possible.

In states where peach growing is now a large and specialized industry, as in portions of the South, the Alleghany States, the Pacific Slope and elsewhere, the officials charged with the protection of these industries from introduced insect pests will no doubt give careful consideration as to what should be done under the circumstances, considering in this connection the extreme difficulty of putting in operation measures which would really prevent the movement of the pest in fruits.

It is pretty certain that the oriental fruit moth will not be very troublesome to apple growers, since the methods of control employed for the codling-moth should also secure the control of this insect. In the case of peaches, however, the situation is not so favorable, since owing to the habits of the pest, it will be very difficult to materially control it by sprays, judging from results of experimental work along this line thus far carried out.

Mr. J. G. SANDERS: I would like to ask Professor Quaintance whether he thinks it possible or probable that European authorities may quarantine against American apples on account of this insect.

Mr. A. L. QuAINTANCE: That is a question I cannot answer. I 
think European authorities have very rarely quarantined against American fruits on the grounds of danger of introduction of injurious insects. It is true that the German Empire and one or two other goverments quarantined American apples on account of the San José scale. It is my understanding, however, that in the case of Germany this quarantine was not issued so much on account of the San José scale as to favor growers of apples in that country. Personally, I do not believe Europe will quarantine against the oriental fruit moth.

Mr. T. J. Headlee: We do not want any misconception concerning the measures that are taken to prevent the distribution of the Japanese beetle on nursery stock into other parts of the United States. From the time the existence of this insect was recognized no plants have been allowed to leave the infested sections of the nursery without having all the soil removed from the roots. In view of the fact that the plants are moved when the Japanese beetle is in the ground as a grub, such precautions would seem ample to prevent the distribution of the insect on nursery stock.

Mr. E. N. Cory: You don't attempt to control the action of the individual in taking plants out of the areas?

Mr. T. J. HeadleE: In response to Mr. Cory's question, up to the past season we have made no attempt to prevent individuals from carrying in hand, bag or vehicle, individual plants such as rosebushes from premises within the infested area. During the past season a campaign of education was put on among the people living in the infested district for the purpose of obtaining their coöperation in the prevention of this sort of movement. During the coming year still greater and we hope more effective efforts will be taken along this line.

President E. D. Ball: The next paper is entitled "High Temperature Fumigation and Methods of Estimating Radiation Required," by W. H. Goodwin.

\section{HIGH TEMPERATURE FUMIGATION AND METHODS OF ESTIMATING RADIATION REQUIRED}

By W. H. Goodwis, New Brunswick, N.J.

(Withdrawn for publication elsewhere)

Vice-President W. C. O'Kane: The next paper on the program is "The Potato Leaf Hopper," by E. D. Ball. 